\title{
Chromate-Reducing Profile of Bacterial Strains Isolated from Industrial Effluents
}

\author{
Fariha Zakria Rizvi, Wajiha Kanwal, Muhammad Faisal* \\ Department of Microbiology and Molecular Genetics, University of the Punjab, \\ Quaid-e-Azam Campus, Lahore, 54590, Pakistan
}

Received: 6 October 2015

Accepted: 20 February 2016

\begin{abstract}
Initially 73 chromium(VI)-resisting bacteria were isolated from nine samples collected from three industrial cities (Kasur, Kalashahkaku, and Sialkot) of Pakistan. Eleven strains with the highest chromium resistance also were selected. Among these highly resistant selected isolates (MTC $\geq 250 \mathrm{mM}$ ), AM81 (Cellulosimicrobium cellulans) showed the highest MTC of $375 \mathrm{mM}$ against $\mathrm{Cr}(\mathrm{VI})$. Biochemical characterization was used to identify the families of bacteria after initial screening. Four isolates shared origin with Staphylococcaceae - three each with Promicromonosporaceae and Microbacteriaceae, and a single strain was related to Bacillales Family XII incertaesedis. 16S rRNA was used for species identification and found KM2 to be Leucobacter chironomid, KS1W; Microbacterium sp., SIS21 and KSKE42; Staphylococcus saprophyticus, SIS22; Staphylococcus sciuri, SIS51; Staphylococcus xylosus, MWM81, AM81, and KSKE3; Cellulosimicrobium cellulans, MWM82; and Microbacterium paraoxydans, KSKE41 was Exiguobacterium profundum. Strains tolerated the stress of other heavy metals (cadmium, mercury, copper, zinc, arsenic, and manganese) to variable extant along with chromium(VI). Antibiotic susceptibility was found to be more for streptomycin $\left(10 \mu \mathrm{g} \mathrm{ml}^{-1}\right)$ and the least susceptibility was observed for kanamycin $\left(30 \mu \mathrm{g} \mathrm{ml}^{-1}\right)$.
\end{abstract}

Keywords: Hexavalent chromium, wastewater treatment, metal resistance, water pollution, bioremediation

\section{Introduction}

Industries are continuously releasing large concentrations of chromium(VI), which has caused the toxic contamination of soil and water systems due to its teratogenic, mutagenic, and carcinogenic properties [1]. Chromium has extensive industrial applications (i.e., in metallurgy, leather tanning, glass staining, wood preservation, aluminum anodization [2], cement production, aircraft production, negative/film developing,

*e-mail: faisal.mmg@pu.edu.pk and nuclear energy) [3]. Chromium can exist from +2 to +6 oxidation states, but $\mathrm{Cr}$ (III) and $\mathrm{Cr}$ (VI) are the center of attention [4]. Trivalent chromium is less toxic as compared to hexavalent chromium, so $\mathrm{Cr}(\mathrm{VI})$ to $\mathrm{Cr}$ (III) conversion is a proficient way to combat its contamination. $\mathrm{Cr}(\mathrm{VI})$, being water soluble, easily crosses the cell membrane while $\mathrm{Cr}$ (III) forms water-insoluble precipitates, so its easy removal makes it less toxic [5]. Chromate oxyanions has structural similarity to $\mathrm{SO}_{4}^{-2}$, so its moves through nonspecific phosphate/sulphate anionic transporters across plasma membranes of both eukaryotic as well as bacterial cells. After absorption, it is reduced to $\mathrm{C}(\mathrm{V})$ radical, which helps in the formation of reactive oxygen species 
(ROS). The oxidative stress results in DNA damage and modulates the action of the p53 gene (apoptotic and tumor suppressor) and causes carcinogenicity [6]. The U.S. Environmental Protection Agency has categorized hexavalent chromium as a known human carcinogen via inhalation (one of among 17 life-threatening chemicals), and has declared $\mathrm{Cr}$ (III) a non-carcinogen [7].

Remediation of chromium is necessary so as to avoid the toxicity due to its contamination. Conventionally, it was removed by ion exchange, precipitation, adsorption, chemical reduction, and membrane separation, but these are expensive [8]. Attention has been diverted toward remediation through cost-effective and ecofriendly biomaterials. $\mathrm{Cr}(\mathrm{VI})$ could be removed from wastewater by bacteria, fungi, and algae, and these could be applied to industrial as well as agricultural wastes [9]. Microorganisms have the ability to tolerate noxious metal-contaminated environments. This tolerance is mediated by resistance genes preset in plasmid, DNA methylation, adsorption uptake, metal efflux channels, and enzymatic reduction of metals (metal biotransformation), or by combining metals with other metabolites (i.e., metal is immobilized so it no longer remains toxic for the environment) [10]. Bacteria with high chromium-reducing ability include E.coli, Agrobacterium, Enterobacter, Shewanella, Thermus, Bacillus, and Pseudomonas [11].

The present study was carried out to check the profile of chromium-resistant bacteria present in polluted areas, as well as to check their chromate reduction potential.

\section{Material and Methods}

\section{Isolation of Strains}

Sample collection sites were three industrially contaminated cities of Pakistan (Sialkot, Kasur, and Kala Shah Kaku). Samples included both soil and effluent. The $\mathrm{pH}$ and temperature were recorded on site. Serial dilutions were inoculated on Luria Bertani agar plates supplemented with $5 \mathrm{mM}$ hexavalent chromium salt and incubated overnight at $37^{\circ} \mathrm{C}$.

\section{Minimum Inhibitory Concentration}

Minimum inhibitory concentration (MIC) was determined to select strains that could resist high concentrations of chromium. For this purpose, bacterial inoculums were prepared in LB broth supplemented with varying concentrations of potassium chromate: 10, 20, 30, $40,50,60,70,80,100,125,150,175,200$, and $250 \mathrm{mM}$. Shaking cultures (200 rpm) were incubated at $37^{\circ} \mathrm{C}$ for 72 hours.

\section{Chromium Reduction Screening}

Reduction of chromium was estimated using the protocol reported by Clesceri et al. [12]. After inoculation into DeLeo and Ehrlich [13] medium, Cr(VI) reduction by bacteria was examined by spectrophotometery of the supernatant (O.D at $540 \mathrm{~nm}$ ). To calculate $\mathrm{Cr}$ (VI) concentration, a calibration curve was established using standard solutions with $0.1 \mathrm{mM}$ to $2 \mathrm{mM}$ of $\mathrm{Cr}(\mathrm{VI})$.

\section{Morphologic and Biochemical Analysis}

Selected strains were morphologically, biochemically, and physiologically characterized. Morphological characterization was done by viewing colony morphology as well as cell morphology. Biochemical characterization was done using catalase, oxidase, and other tests, i.e., carbohydrate fermentation (lactose, starch, sucrose, and mannitol). We also performed the nitrate reduction and arginine hydrolysis test.

\section{S rRNA Analysis for Genetic Characterization}

All the isolated chromium-resistant bacteria were refreshed and shipped to Macrogen, Inc. for 16S rRNA analysis. A DNA template was prepared for PCR. 1492R (TAC ggY TAC CTT gTT ACg ACT T) and 27F (AgA gTT TgA TCM TGG CTC Ag) were the universal primers. PCR products of approx. 1,400 bp were sequenced (Applied BioSystems, USA) by using two universal primers: 800R (TAC CAg ggT ATC TAA TCC) and 518F (CCA gCA gCC gCg gTA ATA Cg). Sequencing products were analyzed on an automated (Applied BioSystems, USA) DNA sequencing system. Nucleotide sequence was analyzed using MEGABLAST [14].

\section{Physiological Characteristics}

The multiple metal tolerance profile of chromiumresistant bacterial strains was characterized by testing with different concentrations of: $\mathrm{Zn}^{2+}\left(\mathrm{ZnSO}_{4}\right), \mathrm{Hg}^{2+}$ $\left(\mathrm{HgCl}_{2}\right), \mathrm{Cu}^{2+}\left(\mathrm{CuSO}_{4}\right), \mathrm{Mn}^{2+}\left(\mathrm{MnSO}_{4}\right), \mathrm{Cd}^{2+}\left(\mathrm{CdCl}_{2}\right)$, and $\mathrm{As}^{6+}\left(\mathrm{Na}_{2} \mathrm{HAsO}_{4}\right)$. The antibiotic susceptibility profile was checked with different antibiotics: ampicillin (Amp) - $25 \mu \mathrm{g} \mathrm{ml}{ }^{-1}$, oxytetracyclin (T) $-30 \mu \mathrm{g} \mathrm{ml} \mathrm{m}^{-1}$, erythromycin (E) - $15 \mu \mathrm{g} \mathrm{ml}^{-1}$, chloramphenicol (C) - 30 $\mu \mathrm{g} \mathrm{ml}{ }^{-1}$, treptomycin (STM) $-10 \mu \mathrm{g} \mathrm{ml}^{-1}$, and Kanamycin

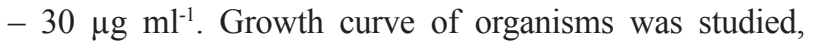
both in the presence $\left(\mathrm{Cr}(\mathrm{VI}) ; 500 \mu \mathrm{g} \mathrm{ml}^{-1}\right)$ and absence of chromium. O.D $(600 \mathrm{~nm})$ of inoculated LB broth was taken after 2, 4, 8, 12, 18, 24, 36, 48, 60, 72, and 96 hours. Triplicate cultures were used for each strain [15]. To check for the effects of $\mathrm{pH}$ on bacterial growth, $100 \mu \mathrm{l}$ of bacterial inoculums were used for different $\mathrm{pH}$ levels $(3,5,7$, and 9) of the $\mathrm{LB}$ broth (amended with 0 and $0.5 \mathrm{mg} / \mathrm{ml}$ of $\mathrm{K}_{2} \mathrm{CrO}_{4}$ ). The experiment was performed in triplicate for each $\mathrm{pH}$.

Different temperatures, i.e., $28^{\circ} \mathrm{C}, 37^{\circ} \mathrm{C}$, and $45^{\circ} \mathrm{C}$ were studied for their possible impact on bacterial growth. Inoculum was given in L-broth (with and without $0.5 \mathrm{mg}$ $\mathrm{ml}^{-1} \mathrm{~K}_{2} \mathrm{CrO}_{4}$ ) and incubated at different temperatures for 24 hours. Triplicate for each strain and temperature was taken. 


\section{Nutritional Requirement of Chromium-Resistant Bacteria}

Two experiments were performed to check for any effect of nutrients on bacterial growth. Firstly, to check the nutritional requirement strains were inoculated in eight different sets of tubes containing different nutrients. In each tube, Tanners medium with a $20 \mathrm{mM}$ PIPES buffer was used along/in combination with substrates $(10 \mathrm{mM}$ glucose, $1 \%$ yeast extract, or $1 \%$ casein). In the second experiment, the minimum nutritional requirement was determined by inoculating the Tanners medium with 20 mM PIPES buffer supplemented with $0.1 \%, 0.25 \%$, and $0.5 \%$ concentrations of yeast extract. Both experiments were run in triplicate.

To determine the chromium reduction potential of bacteria, Tanners medium with $20 \mathrm{mM}$ PIPES and yeast extract $(0.1 \%)$ was used to inoculate the strains. Pellet was obtained and suspended into PIPES buffer $(20 \mathrm{mM})$ supplemented with either $0.1 \%$ yeast extract or $10 \mathrm{mM}$ glucose, or both. After adding $1 \mathrm{mM} \mathrm{Cr}(\mathrm{VI})$, flasks were placed on shaker at $37^{\circ} \mathrm{C}$ and O.D was taken at intervals.

Biological chromate reduction was checked by inoculating strains in six sets of tubes. All tubes had Tanners medium and $20 \mathrm{mM}$ PIPES buffer. Two sets were used as positive and negative controls. The second set contained $1 \mathrm{mM} \mathrm{Cr}(\mathrm{VI})$, the third set had yeast extract $(0.1 \%)$ and $1 \mathrm{mM} \mathrm{Cr}(\mathrm{VI})$, the fourth had citric acid $(0.1 \%)$ and $1 \mathrm{mM} \mathrm{Cr}(\mathrm{VI})$, and tubes of the fifth set had yeast extract $(0.1 \%)$ and $1 \mathrm{mM} \mathrm{Cr}(\mathrm{VI})$. Following the diphenylcarbazide method, O.D was noted for the first at time at 0 , and then at 24,48 , and 72 hours.

\section{Results}

\section{Isolation and Biological Characterization of Strains}

Serially diluted soil and effluent samples were inoculated on LB agar plates with chromium salt. Initially, 73 morphologically distinct colonies were selected and purified after having survived the chromium stress. Twenty-five isolates resisted chromate at high concentration. The maximum tolerable concentration (MTC) of chromium was determined for each of 25 strains. Eleven isolates that had MTC $\geq 250 \mathrm{mM}$ were finalized: KS1W, SIS21, KSKE3, KM2, SIS22, MWM81, SIS51, MWM82, KSKE41, AM81, and KSKE42. 375 mM was the highest MTC observed against chromium(VI) among AM81 (gram-positive rods), whereas isolates MWM82, KM2, KSKE42, and SIS51 resisted up to $350 \mathrm{mM}$ of $\mathrm{Cr}(\mathrm{VI})$ (Fig. 1).

All chromium-resistant strains were found to be Gram positive. SIS22, KSKE41, SIS51, KSKE42, and SIS21 were found to be cocci, and the other was rodshaped. All strains were capsulated except KM2, AM81, and MWM81. Endospore formation was not observed in any of the strains. Each isolate was positive for catalase

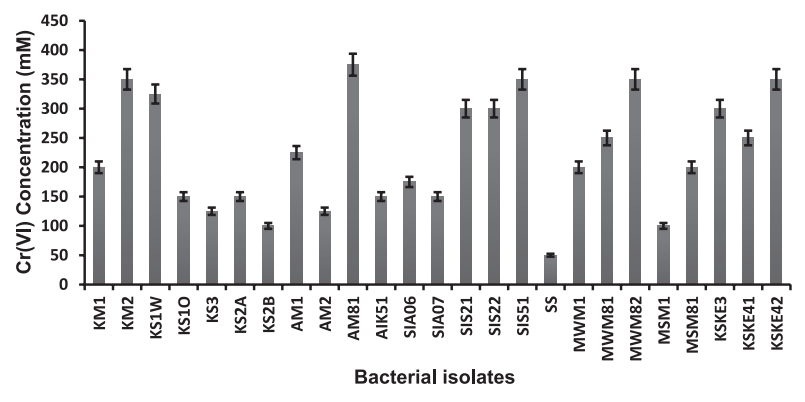

Fig. 1. Maximum tolerable concentrations of hexavalent chromium for bacterial isolates.

enzyme production. The majority of the strains were oxidase negative except for AM81, MWM81, and KSKE3. No strict anaerobe was found, i.e., each strain was either aerobe or facultative anaerobe. The majority of isolates were able to assimilate sugars, i.e., glucose, mannitol, lactose, and sucrose. The isolate KM2 was an exception that did not consume any sugars in its energy production. The characteristics and biochemical properties of the isolates are specified in Table 1.

\section{Physiological Characterization}

\section{Bacterial Growth Curve}

$\mathrm{Cr}(\mathrm{VI})$ stress had no pronounced effect on the growth rate of bacterial isolates with th exception of those of KSKE42. The majority of the strains entered into log phase after two hours of incubation, despite the absence or presence of metal stress. AM81 and MWM81 showed extended log phase, i.e., 12-24 hours. Simultaneously, $\mathrm{Cr}(\mathrm{VI})$ also affected the death phase of SIS21 and KSKE42, which started just after 12 and 8 hours of incubation, respectively, while in metal free cultures isolates entered the death phase after 24 hours. The detailed results of the growth curve are written in Fig. 2.

\section{Effects of Temperature and $p H$ on Bacterial Growth}

Although all the isolates preferred neutral $\mathrm{pH}$ for their growth, they were also able to grow in alkaline $\mathrm{pH}$ (i.e., 9). Strains show sensitivity toward acidic pH, but KSKE3, KSKE41, and KSKE42 were able to grow at pH 5 (Fig. 3). The most suitable temperature for the majority of isolates was $37^{\circ} \mathrm{C}$, followed by $45^{\circ} \mathrm{C}$. KM2, SIS21, and KSKE42 were the best grower at $45^{\circ} \mathrm{C}$, and the growth of strains was reduced at $28^{\circ} \mathrm{C} \mathrm{(Fig.} \mathrm{4).}$

\section{Metal Resistance}

The majority of strains resisted other heavy metals besides chromium. Cadmium chloride was found to be inhibitory for the majority of isolates. However, strains MWM81, AM81, KS1W, and MWM 82 resisted up to $4 \mathrm{mM}$ of $\mathrm{CdCl}_{2}$, while KSKE3 easily tolerated up to $5 \mathrm{mM}$. Isolates also showed resistance to lower concentrations 
Table 1. Characteristics of $\mathrm{Cr}(\mathrm{VI})$-resistant bacterial isolates.

\begin{tabular}{|c|c|c|c|c|c|c|c|c|}
\hline Strains & $\begin{array}{l}\text { MacConkey } \\
\text { Agar }\end{array}$ & $\begin{array}{l}\text { EMB } \\
\text { Agar }\end{array}$ & $\begin{array}{l}\text { O.F } \\
\text { Test }\end{array}$ & $\begin{array}{l}\text { Starch Hydro- } \\
\text { lysis }\end{array}$ & $\begin{array}{l}\text { Nitrate } \\
\text { Reduction }\end{array}$ & Lactose & $\begin{array}{l}\text { Arginine } \\
\text { Hydrolysis }\end{array}$ & $\begin{array}{c}\mathrm{H}_{2} \mathrm{~S} \text { on } \mathrm{SIM} \\
\text { Agar }\end{array}$ \\
\hline KM2 & NF & -ve & A & $+\mathrm{ve}$ & $+\mathrm{ve}$ & -ve & -ve & -ve \\
\hline KS1W & NF & -ve & A & -ve & -ve & -ve & -ve & -ve \\
\hline AM81 & LF & $+\mathrm{ve}$ & F.A & $+\mathrm{ve}$ & $+\mathrm{ve}$ & $+\mathrm{ve}$ & -ve & -ve \\
\hline SIS21 & LF & $+\mathrm{ve}$ & F.A & +ve & $+\mathrm{ve}$ & $+\mathrm{ve}$ & -ve & -ve \\
\hline SIS22 & LF & $+\mathrm{ve}$ & F.A & +ve & $+\mathrm{ve}$ & $+\mathrm{ve}$ & -ve & -ve \\
\hline SIS51 & LF & $+\mathrm{ve}$ & F.A & +ve & $+\mathrm{ve}$ & $+\mathrm{ve}$ & -ve & -ve \\
\hline MWM81 & LF & $+\mathrm{ve}$ & F.A & +ve & $+\mathrm{ve}$ & $+\mathrm{ve}$ & -ve & -ve \\
\hline MWM82 & NF & -ve & A & -ve & -ve & -ve & -ve & -ve \\
\hline KSKE3 & LF & $+\mathrm{ve}$ & F.A & $+\mathrm{ve}$ & $+\mathrm{ve}$ & $+\mathrm{ve}$ & -ve & -ve \\
\hline KSKE41 & LF & -ve & F.A & +ve & $+\mathrm{ve}$ & $+\mathrm{ve}$ & -ve & -ve \\
\hline KSKE42 & LF & $+\mathrm{ve}$ & F.A & $+\mathrm{ve}$ & $+\mathrm{ve}$ & $+\mathrm{ve}$ & -ve & -ve \\
\hline
\end{tabular}

Oxidation Fermentation (O.F), Aerobes (A), Facultative Anaerobes (F.A), Positive (+ive), Negative (-ve), Non-Fermenter (NF); LF, Lactose Fermenter (LF).

of $\mathrm{HgCl}_{2}$, except KM2 and KSKE41. All strains tolerated the $\mathrm{CuSO}_{4}$ stress at different concentrations. MWM81 and KSKE3 were most efficient at resisting high concentrations of various heavy metals, i.e., $5 \mathrm{mM}$ for $\mathrm{CuSO}_{4}, 6 \mathrm{mM}$ of $\mathrm{ZnSO} 4,8 \mathrm{mM}$ of $\mathrm{Na}_{2} \mathrm{HAsO}_{4}$, and $8 \mathrm{mM}$ of $\mathrm{MnSO}_{4}$. However, resistance to $\mathrm{MnSO}_{4}$ (i.e., $14 \mathrm{mM}$ ) was conferred by isolates SIS51, SIS21, KSKE41, SIS22, and KSKE42 (Fig. 5).

\section{Antibiotic Resistance}

Antibiotic susceptibility of the chromium-resistant bacteria is mentioned in Table 2. KSKE41 and KM2 were the only isolates susceptible to all the tested antibiotics. Isolates KS1W and MWM82 showed resistance to the maximum number of antibiotics, i.e., ampicillin $\left(25 \mu \mathrm{g} \mathrm{ml}^{-1}\right)$, erythromycin $\left(15 \mu \mathrm{g} \mathrm{ml}^{-1}\right)$, chloramphenicol

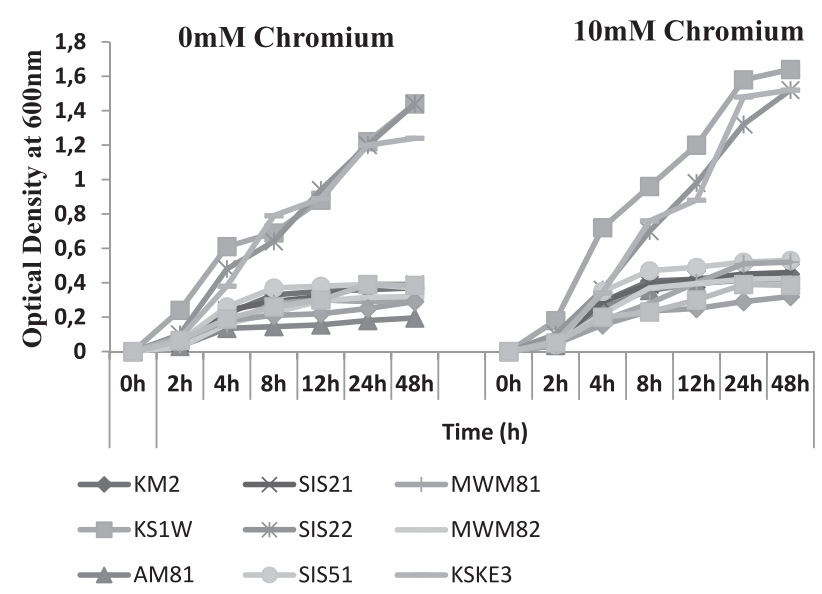

Fig. 2. Growth curve of isolates with $0 \mathrm{mM} \mathrm{Cr}(\mathrm{VI})$ and $10 \mathrm{mM}$ Cr(VI).
(30 $\left.\mu \mathrm{g} \mathrm{ml}^{-1}\right)$, and oxytetracycline $\left(30 \mu \mathrm{g} \mathrm{ml}^{-1}\right)$. Antibiotics resisted by the maximum number of strains were chloramphenicol $\left(30 \mu \mathrm{g} \mathrm{ml}^{-1}\right)$, kanamycin $\left(30 \mu \mathrm{g} \mathrm{ml}^{-1}\right)$, and erythromycin $\left(15 \mu \mathrm{g} \mathrm{ml}^{-1}\right)$. Streptomycin $\left(10 \mu \mathrm{g} \mathrm{ml}^{-1}\right)$ inhibited the growth of the majority of isolates.

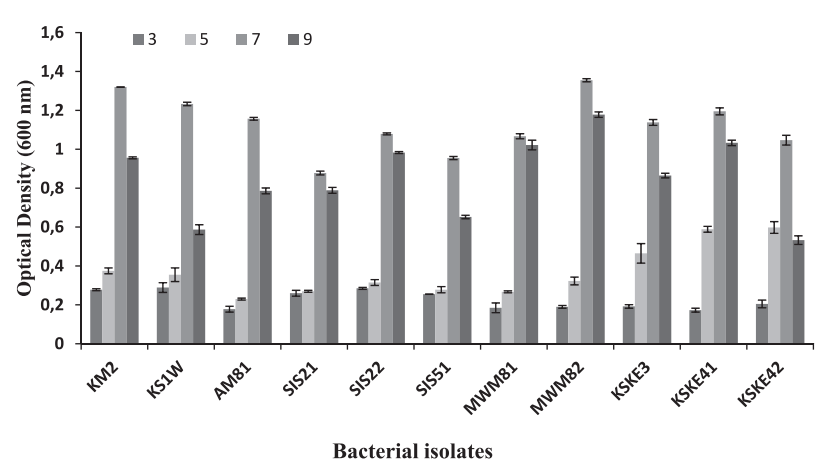

Fig. 3. Determination of optimum $\mathrm{pH}$ for growth of bacterial isolates. Maximum growth was observed at $\mathrm{pH} 7$ and minimum at $\mathrm{pH} 3$.

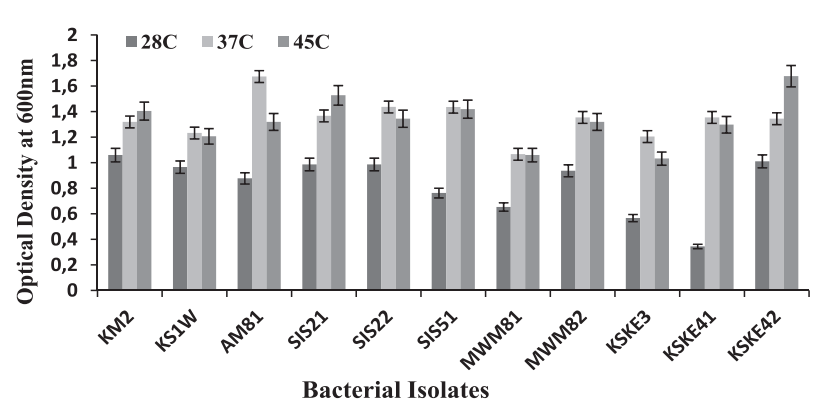

Fig. 4. Optimum temperatures for bacterial growth: isolates either showed their highest growth at $37^{\circ} \mathrm{C}$ or at $45^{\circ} \mathrm{C}$; least growth was observed at $28^{\circ} \mathrm{C}$. 


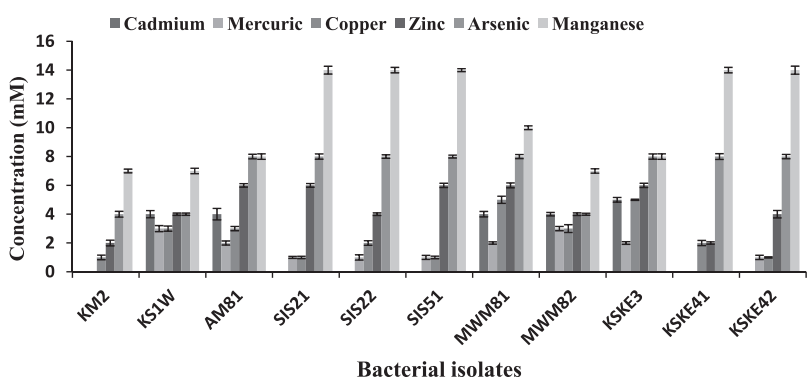

Fig. 5. Heavy metal resistance profiles of bacterial isolates.

\section{Nutritional Requirements}

Yeast extract enhanced bacterial growth more efficiently as compared to glucose and casein. Enhanced growth of strains was observed in tubes having basal medium supplemented with either yeast extract alone or a combination of yeast extract with other nutrients (Figs $6 \mathrm{a}, \mathrm{b})$. The KS1W strain thrived only in yeast extractsupplemented medium, and negligible growth of the isolate was observed in yeast extract-deficient medium. Increasing concentrations of yeast extract ( 0.1 to $1.0 \%)$ had a pronounced effect on bacterial growth. Few of the isolates showed enhanced growth even at $0.1 \%$ yeast extract concentration (Fig. 7).

The family origin of strains was determined by combining the results of morphological identification and biochemical analysis of strains. Strains SIS51, SIS21, KSKE42, and SIS22 were affiliated with the Staphylococcaceae family; AM81, KSKE3, and MWM81 with Promicromonosporaceae; KS1W, MWM82, and KM2 shared most of the characteristics with the Microbacteriaceae family; and KSKE41 showed lineage to the Bacillales Family XII Incertae Sedis.
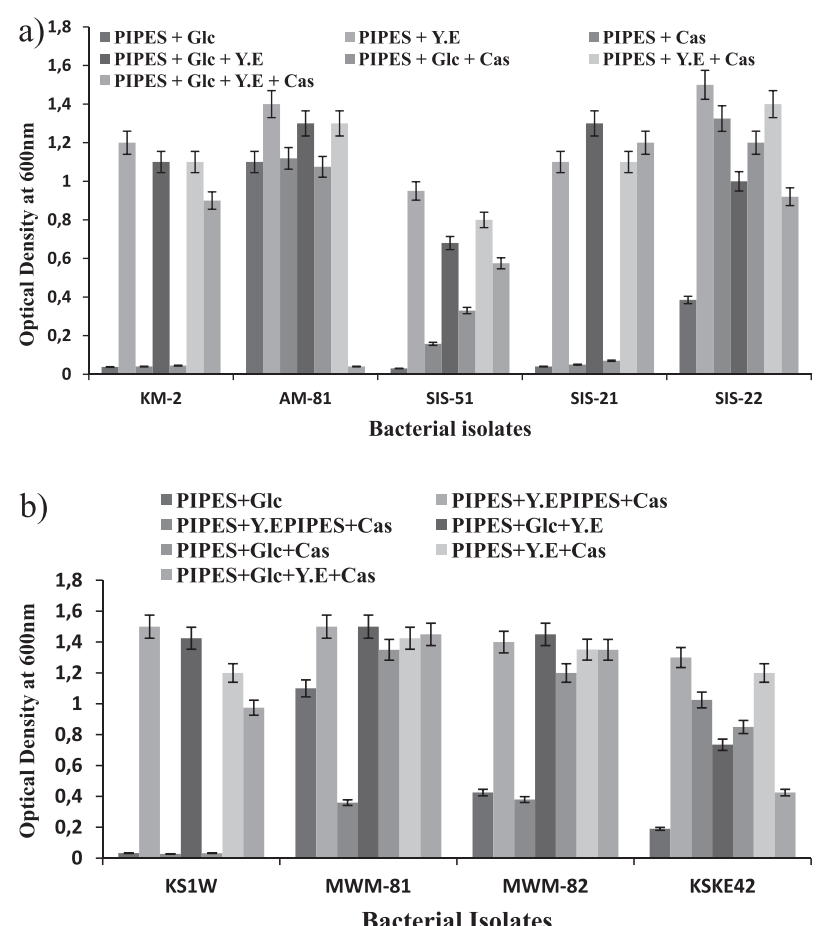

Fig. 6. a) Growth of $\mathrm{Cr}(\mathrm{VI})$-resistant bacteria in basal medium with variable nutritional components, b) Growth of $\mathrm{Cr}(\mathrm{VI})$ resistant bacteria in basal medium with variable nutritional components.

The 16S rRNA gene sequencing analysis led to the bacterial species identification. BLAST analysis illustrated the lineages of all strains. KSKE3, AM81, and MWM81 presented maximum homology $(99 \%, 100 \%$, and $99 \%)$ for isolates of Cellulosimicrobium cellulans. Other identified strains along with their accession numbers are given in Table 3.

Table 2. Antibiotic resistance profiles of chromium(VI)-resistant isolates.

\begin{tabular}{|c|c|c|c|c|c|c|}
\hline Isolates & $\begin{array}{c}\mathrm{C} \\
\left(30 \mu \mathrm{g} \mathrm{ml}^{-1}\right)\end{array}$ & $\begin{array}{c}\mathrm{Amp} \\
\left(25 \mu \mathrm{g} \mathrm{ml}^{-1}\right)\end{array}$ & $\begin{array}{c}\mathrm{T} \\
\left(30 \mu \mathrm{g} \mathrm{ml}^{-1}\right)\end{array}$ & $\begin{array}{c}\text { STR } \\
\left(10 \mu \mathrm{g} \mathrm{ml}^{-1}\right)\end{array}$ & $\begin{array}{c}\mathrm{E} \\
\left(15 \mu \mathrm{g} \mathrm{ml}^{-1}\right)\end{array}$ & $\begin{array}{c}\text { KAN } \\
\left(30 \mu \mathrm{g} \mathrm{ml}^{-1}\right)\end{array}$ \\
\hline KM2 & $\mathrm{S}$ & $\mathrm{S}$ & $\mathrm{S}$ & S & S & S \\
\hline $\mathrm{KS} 1 \mathrm{~W}$ & $\mathrm{R}$ & $\mathrm{R}$ & $\mathrm{R}$ & $\mathrm{S}$ & $\mathrm{R}$ & $\mathrm{S}$ \\
\hline AM81 & S & $\mathrm{S}$ & S & $\mathrm{S}$ & $\mathrm{S}$ & $\mathrm{R}$ \\
\hline SIS21 & $\mathrm{R}$ & S & S & S & $\mathrm{R}$ & $\mathrm{R}$ \\
\hline SIS22 & $\mathrm{R}$ & S & S & S & $\mathrm{R}$ & $\mathrm{R}$ \\
\hline SIS51 & $\mathrm{R}$ & S & S & $\mathrm{S}$ & $\mathrm{R}$ & $\mathrm{R}$ \\
\hline MWM81 & S & S & S & $\mathrm{S}$ & $\mathrm{S}$ & $\mathrm{R}$ \\
\hline MWM82 & $\mathrm{R}$ & $\mathrm{R}$ & $\mathrm{R}$ & $\mathrm{S}$ & $\mathrm{R}$ & S \\
\hline KSKE3 & $\mathrm{S}$ & S & S & $\mathrm{S}$ & $\mathrm{S}$ & $\mathrm{R}$ \\
\hline KSKE41 & $\mathrm{S}$ & $\mathrm{S}$ & S & $\mathrm{S}$ & $\mathrm{S}$ & S \\
\hline KSKE42 & $\mathrm{R}$ & S & S & S & $\mathrm{R}$ & $\mathrm{R}$ \\
\hline
\end{tabular}

Chloramphenicol (C), Ampicillin (A), Oxytetracycline (T), Streptomycin (STM), Erythromycin (E), Kanamycin (KAN), Sensitive (S), Resistant (R) 


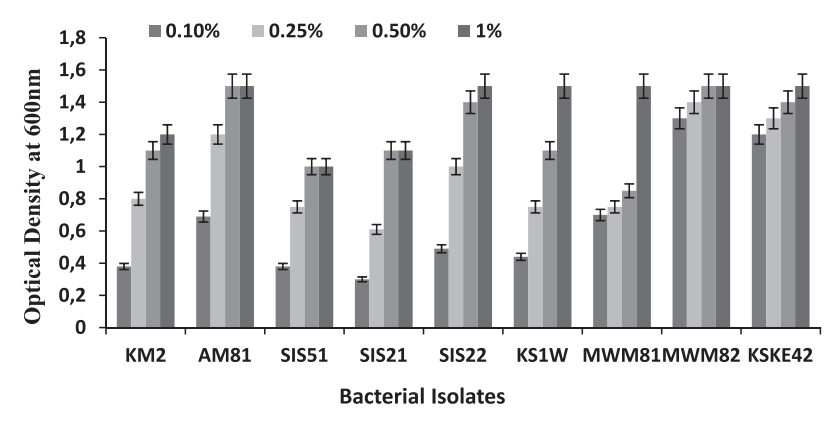

Fig. 7. Growth of bacterial isolates in the basal medium with variable yeast extract percentages.

\section{Discussion}

Chromium metal is well-known due to its toxic, mutagenic, and carcinogenic properties [16]. Various industrial processes use salts of chromium and then wash off their untreated effluents into the environment, which poses harsh coercion to all living organisms, including bacteria. However, microorganisms gradually adapt by developing detoxification mechanisms to survive the stress of pollutants. These detoxification mechanisms of microbes can be exploited for bioremediation of such potent toxicants. Contaminated samples were tested to obtain chromium-resistant bacteria. Among selected strains, AM81 (Gram-positive rods) showed the highest MTC against Cr(VI) (at $375 \mathrm{mM}$ ), whereas isolates SIS51, MWM82, KM2, and KSKE42 resisted up to $350 \mathrm{mM}$ of $\mathrm{Cr}(\mathrm{VI})$ (Fig. 1). Gram-positive bacteria had already been reported with $950 \mathrm{mM}$ of chromate tolerance [17].

Sultan and Hasnain [18] had also reported an isolate having chromate tolerance of $288 \mathrm{mM}$, whereas

Table 3. Identified subject sequences with their GenBank accession numbers used in pintail analysis of the isolates for the detection of chimeric sequences.

\begin{tabular}{|c|c|c|}
\hline \multicolumn{2}{|c|}{ Isolates } & $\begin{array}{c}\text { Subject } \\
\text { Sequences } \\
\text { Accession } \\
\text { Number }\end{array}$ \\
\hline KM2 & Leucobacter chironomid & GU593626 \\
\hline KS1W & Microbacterium sp. & FJ865215 \\
\hline AM81 & Cellulosimicrobium cellulans & KC660138 \\
\hline SIS21 & Staphylococcus saprophyticus & GU097199 \\
\hline SIS22 & Staphylococcus sciuri & JN559391 \\
\hline SIS51 & Staphylococcus xylosus & GQ222240 \\
\hline MWM81 & Cellulosimicrobium cellulans & X79453 \\
\hline MWM82 & Microbacterium paraoxydans & KF254684 \\
\hline KSKE3 & Cellulosimicrobium cellulans & KC660138 \\
\hline KSKE41 & Exiguobacterium profundum & AB681514 \\
\hline KSKE42 & Staphylococcus saprophyticus & NR_074999 \\
\hline
\end{tabular}

Amoozegar et al. [19] reported a bacterial isolate tolerant of up to $600 \mathrm{mM}$ chromate. But the level of chromate resistance among selected isolates is relatively higher than that of the isolates tested by other researchers [20]. All chromium-resistant bacteria were Gram-positive, either cocci or rods. Except KS1W, KM2, and MWM82, all strains were facultative anaerobes (i.e., they could survive both the absence and presence of oxygen).

Stress of chromium metal had different effects on the different strains at various stages of growth cycle. $\mathrm{Cr}(\mathrm{VI})$ stress did not interfere with the duration of the lag phase, which shows that the bacteria had nothing to do with metal at this initial stage, but when they grow to an extent they may start consuming hexavalent chromium as a nutrient. However, an extended lag phase due to chromate is an indication that it interferes with cell growth, i.e., prolonging cell division [21]. However, the majority of strains showed extended log phase, which means that chromate enhances the growth of isolates. At the same time, $\mathrm{Cr}(\mathrm{VI})$ supplementation affected the duration of the death phase of SIS21 and KSKE42, and the cultures entered the death phase after 12 and 8 hours of incubation, respectively. This occurred due to the extensive consumption and hence early deprivation of nutrients during the longer log phase. The growth cycles of some isolates were not influenced by chromate. Different bacteria had been reported in previous studies, and their growth remains unaffected in the chromate presence [22] as the growth pattern remains similar with and without stress. Efficiency of microorganisms can be enhanced by optimizing the growth conditions so that they work effectively as the bioremediator at contaminated sites [23]. Strains preferred to grow in neutral $\mathrm{pH}$ (7) followed by alkaline (9). Acidic $\mathrm{pH}$ changes the cell surface's charge, which is lethal for the cell and hence cell growth decreases. Optimum growth temperature for most of the strain was $37^{\circ} \mathrm{C}$. Few isolates also showed best growth at $45^{\circ} \mathrm{C}$. However, no strain preferred low temperature for its growth.

At most times, nontoxic and toxic compounds coexist at natural territory and it is essential to determine the effects of other metals on bacteria growth [24]. So organisms were tested for their ability to resist several heavy metals $\left(\mathrm{HgCl}_{2}, \mathrm{ZnSO}_{4}, \mathrm{CuSO}_{4}, \mathrm{MnSO}_{4} \mathrm{CdCl}_{2}\right.$, and $\mathrm{Na}_{2} \mathrm{HAsO}_{4}$ ). Each isolate was able to resist these metals to a variable extent. Isolates SIS21, KM1, SIS22, SIS51, KSKE42, and KSKE41 were $\mathrm{CdCl}_{2}$ sensitive and only KSKE41 and $\mathrm{KM} 1$ were susceptible to $\mathrm{HgCl}_{2}$ (i.e., their growth is inhibited in the presence of the respective salts). The remaining bacterial strains were resistant to each of the tested metals. Multiple metals' tolerance is a necessity of microorganisms to survive such an environment loaded with a variety of heavy metals [21]. Faisal and Hasnain [25] reported chromium-resistant bacteria, which were also resistant to multiple heavy metals $(\mathrm{Ni}, \mathrm{Cu}, \mathrm{Co}, \mathrm{Zn}$, $\mathrm{Mn}$, and $\mathrm{Pb}$ ). Cheung and $\mathrm{Gu}$ [26] and Thacker et al. [27] had observed similar results. Abou-Shanab et al. [28] also reported six chromate-resistant strains that were also resistant to $\mathrm{Mn}, \mathrm{Pb}$, and $\mathrm{Zn}$. 
Resistance to antibiotics is also considered an adaptive strategy of bacteria to survive at contaminated sites [24]. Isolates KS1W and MWM82 are resistant to the maximum number of antibiotics, i.e., these could survive metal as well as antibiotic stress. A number of heavy metalresistant bacteria had been reported that resisted several antibiotics [29]. Jain et al. [30] also reported an isolate that tolerated and resisted chromate at high concentration and was resistant to different antibiotics as well. Kharbasizaed et al. [31] also reported similar findings. Heavy metal resistance usually results in antibiotic resistance as well, because the genes encoded for resistance to heavy metals could be positioned next to genes encoding antibiotic resistance [32]. Bacteria preferred yeast extract for their growth as better growth was seen where yeast extract was used alone or supplemented along with other nutrients. This demonstrated the fact that isolates have complex nutritional requirements and yeast extract was found to be important for growth optimization.

Hence, the chromium-resistant bacteria isolated in the present study are resistant to several heavy metals as well as to a variety of antibiotics. These properties could be employed for bioremediation of heavy metals at polluted sites.

\section{References}

1. ZHOU Y., XU Y.B., XU S.H., ZHANG X.H., JX X. The isolation, identification and biochemical reducing pathway of Cr (VI)-removal bacterium Brevibacillus parabrevis from sludge biosystem. In: Wu, Y. [Ed.] International Conference on, Energy Environmental, Engineering CRC Press/ Balkema, Leiden, the Netherlands, 2015.

2. MADHAVI V.I., REDDY A.V.B., REDDY K.G., MADHAVI G., PRASAD T.N.K.V. An overview on research trends in remediation of chromium. Res. J. Recent Sci. 2 (1), 71, 2013.

3. AHEMAD M. Bacterial mechanisms for $\mathrm{Cr}(\mathrm{VI})$ resistance and reduction: an overview and recent advances. Folia Microbiol. 59 (4), 321, 2014.

4. NGUEMA P.F., LUO Z., LIAN J.J. Enzymatic chromium (VI) Reduction by cytoplasmic and cell membrane fractions of chromate-reducing bacterium isolated from sewage treatment plant. Int. J. Biol. 6 (2), 64, 2014.

5. CERVANTES C., CAMPOS-GARCIA J., DEVARS S., GUTIERREZ-CORONA F., LOZA-TAVERA H., TORRES-GUZMAN J.C., MORENO-SANCHEZ R. Interactions of chromium with microorganisms and plants. FEMS Microbiol. Rev. 25 (3), 335, 2001.

6. LIU X., WU G., ZHANG Y., WU D., LI X., LIU P. Chromate reductase YieF from Escherichia coli enhances hexavalent chromium resistance of human HepG2 cells. Int. J. Mol. Sci. 16 (6), 11892-11902, 2015.

7. USEPA. IRIS Toxicological Review of Hexavalent Chromium (External Review Draft). U.S. Environmental Protection Agency, Washington D.C. EPA/635/R- 10/004A, 2010.

8. GOPALAKRISHNAN S., KANNADASAN T., VELMURUGAN S., MUTHU S., KUMAR V.P. Biosorption of chromium (VI) from industrial effluent using Neem leaf adsorbent. Res. J. Chem. Sci. 3 (4), 48, 2013.

9. WANG P., MA Y., WANG C., ZHANG S., CHENG S. Isolation and characterization of heavy metal resistant bacteria capable of removing Cr (VI). Pol. J. Environ. Stud. 24 (1), 339, 2015.

10. PEI Q.H., SHAHIR S., RAJ A.S.S., ZAKARIA Z.A., AHMAD W.A. Chromium (VI) resistance and removal by Acinetobacter haemolyticus. World J. Microbiol. Biotechnol. 25 (6), 1085, 2009.

11. SONI S.K., SINGH R., AWASTHI A., SINGH M., KALRA A. In vitro $\mathrm{Cr}$ (VI) reduction by cell-free extracts of chromate-reducing bacteria isolated from tannery effluent irrigated soil. Environ. Sci. Pollut. Res. 20 (3), 1661, 2013.

12. CLESCERI L.S., GREENBERG A.E., EATON A.D. Standard methods for the examination of water and wastewater. $20^{\text {th }}$ ed. American Public Health Association, Washington. 1325, 1998.

13. DELEO P.C., EHRLICH H.L. Reduction of hexavalent chromium by Pseudomonas fluorescens LB 300 in batch and continuous cultures. Appl. Microbiol. Biotechnol. 40, 756, 1994.

14. ALTSCHUL S.F., MADDEN T.L., SCHAFFER A.A., ZHANG J., ZHANG Z., MILLER W., LIPMAN D.J. Gapped BLAST and PSI-BLAST: a new generation of protein database search programs. Nucl. Acids Res. 25 (17), 3389, 1997.

15. POMMERVILLE J.C., ALCAMO I.E. Alcamo's Laboratory Fundamentals of Microbiology. Jones and Bartlett, Sudbury, MA. 2007.

16. HOLMES A.L., WISE S., WISE S.J.P. Carcinogenicity of hexavalent chromium. Indian J. Med. Res. 128 (4), 353, 2008.

17. SAU G.B., CHATTERJEE S., SINHA S., MUKHERJEE S.K. Isolation and characterization of a $\mathrm{Cr}$ (VI) reducing Bacillus firmus strain from industrial effluents. Pol. J. Microbiol. 57 (4), 327, 2008.

18. SULTAN S., HASNAIN S. Reduction of toxic hexavalent chromium by Ochrobactrum intermedium strain $\mathrm{SDCr}-5$ stimulated by heavy metals. Bioresource Technol. 98 (2), 340, 2007.

19. AMOOZEGAR M.A., GHASEMI A., RAZAVI M.R., NADDAF S. Evaluation of hexavalent chromium reduction by chromate-resistant moderately halophile, Nesterenkonia sp. strain MF2. Process Biochem. 42 (10), 1475, 2007.

20. NARAYANI M., SHETTY K.V. Chromium-resistant bacteria and their environmental condition for hexavalent chromium removal: A review. Crit. Rev. Env. Sci. Tec. $\mathbf{4 3}$ (9), 955, 2013.

21. CHENG G., LI X. Bioreduction of chromium(VI) by Bacillus $\mathrm{sp}$. isolated from soils of iron mineral area. European J. Soil Biol. 45 (5-6), 483, 2009.

22. CHAI L., HUANG S., YANG Z., PENG B., HUANG Y., CHEN Y. Cr (VI) remediation by indigenous bacteria in soils contaminated by chromium-containing slag. J. Hazard. Mater. 167 (1-3), 516, 2009.

23. SHAKOORI A.R. Microorganisms resistant to heavy metals and toxic chemicals as indicators of environmental pollution and their use in bioremediation. Folia Biol. 48 (3-4), 143, 1999.

24. VERMA T., GARG S.K., RAMTEKE P.W. Genetic correlation between chromium resistance and reduction in Bacillus brevis isolated from tannery effluent. J. Appl. Microbiol. 107 (5), 1425, 2009.

25. FAISAL M., HASNAIN S. Beneficial role of hydrophytes in removing $\mathrm{Cr}$ (VI) from wastewater in association with chromate-reducing bacterial strains Ochrobactrum intermedium and Brevibacterium. Int. J. Phytoremediat. 7 (4), 271, 2005.

26. CHEUNG K.H., GU J.D. Chromate reduction by Bacillus 
megaterium TKW3 isolated from marine sediments. World J. Microbiol. Biotechnol. 21 (3), 213, 2005.

27. THACKER U., PARIKH R., SHOUCHE Y., MADAMWAR D. Hexavalent chromium reduction by Providencia sp. Process Biochem. 41 (6), 1332, 2006.

28. ABOU-SHANAB R., ANGLE J., VAN BERKUM P. Chromate-tolerant bacteria for enhanced metal uptake by Eichhornia crassipes (Mart.). Int. J. Phytoremediat. 9 (2), 91-105, 2007.

29. RAJBANSHI A. Study on heavy metal resistant bacteria in Guheswori sewage treatment plant. Our Nature 6 (1), 52, 2009.
30. JAIN P.K., RAMACHANDRAN S., SHUKLA V., BHAKUNI D., VERMA S.K. Characterization of metal and antibiotic resistance in a bacterial population isolated from copper mining industry. Int. J. Integrative Biol 6, 57, 2009.

31. KARBASIZAED V., BADAMI N., EMTIAZI G. Antimicrobial, heavy metal resistance and plasmid profile of coliforms isolated from nosocomial infections in a hospital in Isfahan, Iran. Afr. J. Biotechnol. 2 (10), 379, 2004.

32. BAKER-AUSTIN C., WRIGHT M.S., STEPANAUSKAS R., MCARTHUR J.V. Co-selection of antibiotic and metal resistance. Trends in Microbiol. 14 (4), 176, 2006. 